\title{
MAREK GRUBKA Dominikańska Szkoła Wiary dziesięć lat później
}

Cykl wykładów Dominikańska Szkoła Wiary zapoczątkowany został w Gdańsku, w klasztorze św. Mikołaja na jesieni 2000 r., w trakcie trwającego roku jubileuszowego ${ }^{1}$. Przeznaczony był dla dorosłych poszukujących dla siebie prostej formacji, która stałaby się umocnieniem dla ich wiary nie tylko w aspekcie duchowym, ale również w wymiarze intelektualnym. Właśnie minęło 10 lat od powołania tej szkoły. Jest to właściwy czas, tak się wydaje, na podjęcie krótkiej refleksji i poszukanie odpowiedzi na pytanie o sensowność tego typu działalności. Wydaje się, że istotne również może być krótkie zastanowienie się nad przyszłością takiej idei formacyjnej w perspektywie długoletniego projektu intelektualnego przeznaczonego jako pomoc dorosłym, poszukującym w Kościele formacji stałej.

W liście zatwierdzającym Akta Kapituły Prowincjalnej Dominikanów w Polsce, generał zakonu o. Carlos Azpiroz Costa OP wskazuje Dominikańską Szkołę Wiary, jako jedno z kilku ciekawych dzieł apostolskich ostatnich lat. Pisze o tym następująco: Wasza Prowincja zaangażowana jest już $w$ wiele rożnych dziatań, które sa zgodne z naszym charyzmatem. Trzeba was pochwalić za twórcze inicjatywy, takie jak Dominikańska Szkoła Wiary, Studium Chrześcijańskiego Wschodu, Dominikańska Szkoła Wspótczesności, FilozoficznoTeologiczna Szkoła św. Jacka itd. Wszystko to jest przejawem kreatywności braci $w$ zaradzaniu autentycznym potrzebom katechetycznym i jasna odpowiedziq na potrzebe intelektualnej i duchowej formacji Polaków. [...] Wszystkie te przed-

Marek G R U B K A OP, mgr, doktorant WT UAM, Dublin, e-mail: grubkins@ dominikanie.pl

${ }^{1}$ Pomysłodawcami tego projektu wykładowego byli dwaj dominikanie, autor artykułu oraz ówczesny przeor gdańskiego klasztoru, o. Kr z y s z t of $\mathrm{P}$ o p ł a w s ki. 
sięwzięcia apostolskie świadcza o żywotności waszej Prowincji ${ }^{2}$. Ważne są to słowa, które z jednej strony dowartościowuja podjęte działania, a przy tym osadzają je również w tradycji zakonu dominikanów. Słowa najwyższego przełożonego, kolejnego następcy św. Dominika zachęcają do podjęcia refleksji o doświadczeniu, płynącym z tych zaangażowań. Poza tym wypowiedź generała zakonu skłania również do autorefleksji, aby nie popaść $\mathrm{w}$ samozadowolenie $\mathrm{z}$ osiągniętych sukcesów.

\section{Formacja ludzi świeckich}

Nauczanie Soboru Watykańskiego II mocno dowartościowało rolę świeckich chrześcijan w Kościele. Będąc jedną z istotnych części Kościoła, współtworzą go, a także mają w nim swoje zadania do spełnienia. Swoje powołanie realizują poprzez misję spełnianą w Kościele oraz uświęcanie świata (KK 31). Mają również swój udział w powołaniu do apostolstwa, co znalazło swoje podkreślenie w soborowym Dekrecie o apostolstwie świeckich Apostolicam actuositatem, poprzez stwierdzenie, że obowiqzek i prawo do apostolstwa otrzymuja świeccy na mocy swojego zjednoczenia z Chrystusem-Gtowq. Wszczepieni bowiem przez chrzest w Ciało Mistyczne Chrystusa, utwierdzeni moca Ducha Świętego przez bierzmowanie, sq oni przeznaczeni przez samego Pana do apostolstwa (DA 3).

Podejmowanie zadań apostolskich domaga się dobrego i wielostronnego przygotowania. Jednym $\mathrm{z}$ wymiarów takiego przygotowania, podanych przez dekret soborowy jest formacja doktrynalna z zakresu teologii, etyki i filozofii, zależnie od różnicy wieku, warunków życia i zdolności i zdolności (DA 29). Uzupełnia ona przygotowanie duchowe i wprowadza harmonię w relacjach między fides i ratio $^{3}$.

Formacja ludzi świeckich jest ciekawym zagadnieniem w duszpasterskiej działalności Kościoła. Przesłanie o potrzebie formacji katolików świeckich jest również zawarte w adhortacji apostolskiej Christifideles laici Jana Pawła II. Papież, wraz z ojcami synodalnymi, podkreślił, że formacja świeckich powinna się znaleźć wśród zadań priorytetowych diecezji i wejść do programów duszpasterskich tak, aby ku niej zmierzaty wszystkie wysitki wspólnoty (kaptanów,

\footnotetext{
${ }^{2}$ Por. C. A zpiroz Costa: Do naszego Brata Krzysztofa Poptawskiego, prowincjała, $i$ do Braci Prowincji Polskiej. List Generała Zakonu. W: Akta zwyczajne Kapituty Prowincjalnej Polskiej Prowincji Zakonu Kaznodziejskiego 2010. Warszawa 2010 s. 6.

${ }^{3}$ Por. J a n P a w e 1 I I: Encyklika Fides et ratio. Libreria Editrice Vaticana. Watykan 1998; J. P r z y b yło w ski: Apostolat ewangelizacyjny szansq odnowy duszpasterstwa mtodzieży. W: „Ateneum Kapłańskie”. R. 2002 nr 2(558) s. 341.
} 
świeckich i osób zakonnych) ${ }^{4}$. Formacja ludzi świeckich, zatem ma być działaniem pomagającym ludziom świeckim w odkrywaniu ich powołania oraz by mogli podejmować swoją własną misję. Jednak nie chodzi o to, aby przeciwstawiać życie duchowe prowadzonemu życiu świeckiemu. Ważne jest by pomóc tak ukształtować poszczególnych świeckich wiernych, by w ramach integralnej formacji mogli podjąć realizację własnego powołania i misji w Kościele, jako członków Kościoła a zarazem obywateli ludzkiego społeczeństwa.

Wspomniana adhortacja wskazuje na kilka aspektów formacji ludzi świeckich, która w swym założeniu powinna być całościowa. Po pierwsze, formacja powinna być kształtowaniem ku pełni wiary i pogłębieniem zażyłości z Jezusem Chrystusem. Dalej dokument wskazuje na potrzebę doktrynalnej formacji świeckich katolików, którzy mają być zdolni do uzasadniania swej nadziei we współczesnym świecie (1P 3,15). Ważna rolę $\mathrm{w}$ takim procesie wzrastania pełni wszelkiego rodzaju katechetyczna działalności w duszpasterstwie. Niezbędnym wymiarem takiego nauczania winno być wprowadzenie w znajomość nauki społecznej Kościoła, szczególnie pomocną wszystkim, angażującym się w sprawy społeczne i polityczne. Rozwój wartości ludzkich jest kolejnym elementem takiej formacji. Podkreślono zarazem potrzebę formacji tych, którzy mają formować innych. Ważne jest tutaj zakładanie różnego rodzaju szkół i prowadzenia specjalnych kursów. Skuteczność w dotarciu do szerokiej rzeszy świeckich chrześcijan uzależniona jest od przygotowanych osób, którzy będą mogli służyć w Kościele w różnych miejscach i stowarzyszeniach, w szczególny sposób zaś przy parafiach ${ }^{6}$.

Jedną $\mathrm{z}$ form przygotowanie doktrynalne $\mathrm{w}$ formacji świeckich do podejmowania różnych posług w Kościele i w świecie jest katecheza dorosłych. W powszechnej opinii jest to działalność edukacyjna przeznaczona dla dorosłych chrześcijan, która ma dopełnić ich rozwój do dojrzałości wiary oraz odpowiedzialności w podejmowaniu apostolatu ${ }^{7}$.

${ }^{4}$ J a n P awe $\nmid$ II: Adhortacja apostolska Christifideles laici. Libreria Editrice Vaticana. Watykan 1988 s. 165

${ }^{5}$ Tamże, s. 166-169.

${ }^{6}$ Tamże, s. $170-172$.

${ }^{7}$ R. N i park o: Dorostych katecheza. W: Leksykon teologii pastoralnej. Lublin 2006 s. 183-187; Por. A. Prz y be c ki: Duszpasterstwo akademickie. W: Teologia pastoralna. T. 2. Teologia pastoralna szczegótowa. Lublin 2002 s. 355-357; J. P r z y b y ło w s k i: Wychowanie $i$ formacja chrześcijańska ludzi dorostych a misja duszpasterska Kościoła. „,Studia Gdańskie”. T. 23: 2008 s. 227. 


\section{Doświadczenia w prowadzeniu szkoły wiary przez polskich dominikanów}

\section{Gdańskie początki Dominikańskiej Szkoły Wiary w 2000 roku}

Wielokrotnie podczas rozmów z współbraćmi dominikanami czy też z osobami świeckimi pojawiało się pytanie o początki Dominikańskiej Szkoły Wiary ${ }^{8}$. Zdarzało się, że wiele osób było przekonanych, że ta inicjatywa miała swój początek w Warszawie albo w Krakowie. Zdziwienie wywołuje komunikat, że jednak nie tam, a w Gdańsku i to w 2000 r. wszystko, co związane z DSW miało swój początek.

Inicjatywa powstała dość banalnie i była związana ze szczególnym momentem dziejowym w życiu Kościoła, jakim był Jubileusz Roku 2000. U początku pomysłu stały dwie osoby, które zaproponowały gdańskiej wspólnocie, aby taki cykl wykładów włączyć w program jubileuszowy, który był dość naprędce przygotowany przez gdańską wspólnotę klasztoru dominikanów. Idea cyklu wykładowego nazwanego „Dominikańska Szkoła Wiary” zrodziła się z potrzeby zaproponowania jakiejś drogi dalszej formacji osobom dorosłym. A wszystko za sprawą wspólnych rozmów w klasztorze gdańskim, dotyczących programów na rok Jubileuszu 2000. W tym czasie arcybiskup Tadeusz Gocłowski zaproponował dominikanom, aby kościół św. Mikołaja w Gdańsku włączyć do kościołów stacyjnych, czyli pielgrzymkowych, w obchody roku jubileuszowego w archidiecezji gdańskiej ${ }^{9}$. Stało się to z małym opóźnieniem, bowiem dopiero od uroczystości św. Dominika Była ona dla wspólnoty klasztornej okazją do podjęcia wspólnego myślenia i inicjatyw duszpasterskich. Na przełomie sierpnia i września 2000 r. odbyła się specjalna kapituła klasztorna. Rozmowa zainicjowana przez ówczesnego przeora klasztoru dotyczyła ustalenia propozycji skierowanej dla osób przychodzących do bazyliki św. Mikołaja ${ }^{10}$. Po przyjęciu prostego programu na okres od października do końca grudnia tegoż roku, podjęto konkretne działania, aby również taki cykl wykładowy został wprowadzony w życie. Przygotowano specjalny plakat ogłoszeniowy dla spotkań DSW, który w zainicjowanej wówczas formie towarzyszy gdańskim spotkaniom do dnia dzisiejszego. Postać św. Dominika zachęcała do poszukiwań i refleksji. Plakat był przygotowywany raz na semestr, zarówno jesienny jak i wiosenny ${ }^{11}$. Bo sam pomysł

\footnotetext{
${ }^{8}$ Dalej używa się skrótu DSW.

${ }^{9}$ Stało się to z pewnym opóźnieniem. Bowiem z niewiadomego powodu w Trójmieście wyznaczono jedynie kilka kościołów stacyjnych. Nie było w tym zestawie ani jednego kościoła zakonnego. W centrum starego Gdańska takim kościołem była jedynie Bazylika Mariacka.

${ }^{10}$ Wspomniany już o. Krzys z t of P o pławski był w tym czasie przeorem gdańskiej wspólnoty.

${ }^{11}$ Pierwszy plakat. Autorem plakatu był A rk a di u s z R af le w s k i, który w owym czasie był współwłaścicielem „,Yellow Factory”, małej firmy reklamowej, która bardzo pomagała i zasłu-
} 
szkoły zakładał poinformowanie o wykładach z dużym wyprzedzeniem, aby ci, którzy chcieliby w nich uczestniczyć mogli zaplanować sobie czas na konkretne spotkania. Podobnie dotyczyło to wykładowców, których umawiało się wcześniej. Planowanie wykładów było powiązane z powziętym założeniem ogłaszania wykładów na cały semestr, zarówno jesienny jak i wiosenny.

Plan wykładów przewidywał, że spotkania będą odbywały się w piątek wieczorem o g. 19.00-21.00 oraz w sobotę do południa w g. 9.00-11.30. Całość miała kończyć się w sobotnie przedpołudnie przed g. 12.00, aby ci, którzy zechca, skorzystali z zaproszenia do wspólnej mszy świętej. Chociaż projekt szkoły rościł sobie prawa do bycia małym programem wykładowym, to jednak w istocie swojej był to projekt duszpasterski. Skierowany był do grupy osób, która mogła się zmieniać, co miesiąc, w zależności od zaproponowanych tematów i wykładowców. Równie dobrze mogło się zdarzyć, że grupy uczestników mogły się zmienić ze względu na różnorodność proponowanych tematów. Wszystko zależało od sposobu ułożenia programu, a więc doboru tematów i wykładowców.

Po wszystkich ustaleniach szkoła wystartowała. Plakat został powieszony w kościele i w wielu miejscach poza klasztorem. Pierwszy wykład w ramach Dominikańskiej Szkoły Wiary miał miejsce w Gdańsku 21 października 2000 r. Spotkanie poprowadził ojciec Jacek Salij, dominikański profesor teologii dogmatycznej z Warszawy, który zaproponował temat „Wokół dokumentu Dominus Iesus"12. I tak przez 10 lat proponowano różne spotkania ${ }^{13}$. Dotychczas odbyło się 81 wykładów ${ }^{14}$. Wygłosili je tylko dominikanie. Bardzo szybko daje się jednak zauważyć brak osób świeckich w zestawie proponowanych wykładowców.

Szeroka tematyka wykładów obejmuje wiele różnych zagadnień i sprawia, że trudno znaleźć jednolity układ programu. Niektóre z tematów są podejmowane ze względu na aktualnie toczące się dyskusje społeczno-polityczne. Wiele z tematów dotyczy ważnych zagadnień z filozofii i teologii oraz teologii duchowości. Dobór wykładowców i tematów wydaje się przypadkowy.

żyła się przy tworzeniu tego projektu - por. http://www.szkolawiary.dominikanie.pl/gdansk/; Archiwum firmy reklamowej „Yellow Factory” Gdańsk.

${ }^{12}$ Por. Ogłoszenia parafialne. Bazylika św. Mikołaja OO. Dominikanów w Gdańsku X 1999. Archiwum klasztoru św. Mikołaja w Gdańsku.

${ }^{13}$ Dokładny program wykładów za lata 2000-2010 jest podany w aneksie jedynie dla gdańskiego ośrodka. Nie podaje się tutaj programów z innych miejsc, bowiem wiele z tych tematów zostało przez wykładowców powtórzonych w innych ośrodkach. Jednak należy zaznaczyć, że stopniowo każde $\mathrm{z}$ innych miejsc proponowało również swoje tematy i osoby wykładowców, które nie miały odwzorowania $w$ innych programach. Wszystko zależało od indywidualnego rozeznania osoby, która odpowiadała za tworzenie programu albo od grupy osób współtworzących te wykłady.

${ }^{14}$ Czyli w okresie 10 lat, licząc od października 2000 r. do 1 czerwca 2010 r. 
Plan wykładów był tak ogłaszany, że w cyklu jesiennym oraz wiosennym łącznie można było zaprezentować 8-9 tematów. Zasadniczo w pierwotnym układzie wykłady rozpoczynały się w piątek wieczorem i były kontynuowane $\mathrm{w}$ sobotnie przedpołudnie. Począwszy od lutego 2003 r., zmieniła się godzina sobotnich wykładów, mianowicie z dziewiątej na dziesiątą. I taki układ pozostał do dnia dzisiejszego ${ }^{15}$. Podobnie ugruntowała się nazwa własna cyklu wykładów. $\mathrm{Na}$ jeden sezon pojawiało się rozszerzenie w formie Dominikańska Szkoła Wiary i Duchowości. Potem jednak wrócono do pierwotnej nazwy ${ }^{16}$.

Pierwsze dwa lata wykłady DSW były organizowane i koordynowane przez przeora klasztoru o. Krzysztofa Popławskiego. Jego następca, o. Jacek Krzysztofowicz, podjął się prowadzenia tego cyklu. Znamienny jest fakt, że w Gdańsku osoby świeckie nigdy nie współuczestniczyły w przygotowaniu i koordynacji spotkań szkoły wiary ${ }^{17}$. Tylko przeor gdańskiego klasztoru był za to odpowiedzialny. On sam uzgadniał prelegentów i proponował terminy spotkań. Oprócz tego zajmował się zleceniem przygotowania plakatów ogłoszeniowych i biuletynu informacyjnego o spotkaniach ${ }^{18}$.

Osobną inicjatywą gdańskiej wspólnoty były wykłady środowe w ramach cyklu nazwanego Katechezy dla dorostych. Pierwsze spotkanie odbyło się 7 października 2001 r. Taki typ spotkań rozpoznany był, jako uzupełnienie dużych wykładów w ramach DSW. Katechezy odbywać się miały, jako małe spotkania, co tydzień w środę. W założeniu mieli je prowadzić wykładowcy dostępni na miejscu, czyli w klasztorze lub w Trójmieście. Ten cykl wykładowy był prowadzony aż do stycznia 2003 r. i samoczynnie został zawieszony. Wykłady środowe były uzupełniająca propozycją dla Dominikańskiej Szkoły Wiary i prowadzono je własnymi, skromnymi siłami gdańskiego klasztoru. Ta kolejna, choć krótka inicjatywa, wskazuje na kolejny sposób poszukiwania pewnej formy wykładowej (formacyjnej) przeznaczonej dla ludzi dorosłych.

\footnotetext{
${ }^{15}$ Por. Ogłoszenia parafialne. Bazylika św. Mikołaja OO. Dominikanów w Gdańsku II 2000. Archiwum klasztoru św. Mikołaja w Gdańsku.

${ }^{16}$ Dotyczyło to sezonu w latach 2002/2003. Ówczesny, nowy przeor klasztoru, o. J a c e k $\mathrm{K}$ r z y s z t o f o w i c z chciał rozszerzyć zastaną formułę DSW. Jednak proponowana przez niego nazwa nie przyjęła się.

${ }^{17}$ Jest to o tyle istotne, ze w innych ośrodkach klasztornych osoby świeckie bądź świeccy dominikanie współtworzyli to zaangażowanie. Tak się działo między innymi w Szczecinie, Warszawie i Wrocławiu.

${ }^{18}$ Autorem pierwszego plakatu był A r ka di u s z R a fle w s ki, który w owym czasie był współwłaścicielem „Yellow Factory”, małej firmy reklamowej, pomagającej w przygotowaniu materiałów informacyjnych. Firma miała swój wkład przy tworzeniu tego projektu - por. http://www.szkolawiary.dominikanie.pl/gdansk/; Archiwum firmy reklamowej „Yellow Factory” Gdańsk.
} 


\section{Wykłady w innych klasztorach}

Gdańscy pomysłodawcy DSW nie zakładali wielkiego, ogólnopolskiego programu dla tej inicjatywy. Nie spodziewano się, że taki cykl wykładowy będzie miał kontynuację w wielu innych dominikańskich klasztorach. Dobre pomysły same się jednak rozprzestrzeniają i nie trzeba specjalnej reklamy, aby rozwijały się i były podejmowane przez innych. Do rozszerzenia cyklu szkoły wiary na kolejne klasztory dominikańskie w Polsce doszło dość szybko i samorzutnie. Nikt tego nie uzgadniał z ośrodkiem gdańskim. Warto krótko przedstawić, jak inicjatywy DSW mają się w innych ośrodkach dominikańskich.

W klasztorze dominikanów w Szczecinie wykłady rozpoczęto rok później ${ }^{19}$. Pierwszy odbył się 13 października 2001 r. i wygłosił go o. Jacek Salij. Temat brzmiał: „Co to znaczy wierzyć? Co to znaczy wierzyć w Jezusa Chrystusa?”20. Ówczesny przeor o. Witold Słabig zainicjował w ten sposób cały cykl spotkań. W parafialnym piśmie „Dominik” napisano o Dominikańskiej Szkole Wiary, że przyczyni się ona do wzbogacenia wiedzy wszystkich jej uczestników i będzie stanowić stały element formacji religijnej ludzi dorostych ${ }^{21}$. W okresie dziewięciu lata działalności DSW w Szczecinie odbyło się 68 wykładów, z czego 57 wygłosili dominikanie. Sześć wykładów było podjętych przez świeckich wykładowców, w tym była jedna kobieta ${ }^{22}$. Należy zaznaczyć, że w pierwszych latach XXI w. DSW była jedyną tego rodzaju inicjatywą formacyjną w tym mieście. Obecnie istnieje również Akademia Rodzinna, oferująca interesującą propozycję wykładów specjalistycznych dla małżonków.

Warszawski klasztor dominikanów, położony przy ulicy Freta 10, był kolejnym ośrodkiem, gdzie zainaugurowano cykl DSW spotkania w październiku 2002 r. Trudno ustalić, w jaki sposób gdańska idea została przeniesiona do warszawskiego klasztoru. Pierwszy wykład odbył się w drugiej połowie października 2002 r. Poprowadził go ówczesny prowincjał polskich dominikanów o. Maciej Zięba, a temat brzmiał: „O wielbłądzie i uchu igielnym, czyli o pieniądzach, gospodarce i przedsiębiorczości”. Wykłady odbywają się do dnia dzisiejszego, jednak w latach 2008-2009 nastąpiła przerwa. Dotychczas odbyło się ponad 50 wykładów. Obok dominikanów pojawiły się trzy osoby świeckie, w tym jedna

\footnotetext{
${ }^{19}$ Dokładne archiwum z przeprowadzonych przez 9 lat wykładów można znaleźć na stronie szczecińskiego klasztoru - por. http://szkolawiary.szczecin.pl/archiwum.html.

${ }^{20}$ Podobnie było rok wcześniej w Gdańsku. Ojciec Jacek Salij był jednym z tych prelegentów, którego było warto zaprosić na początek. Gwarantował dobrą jakość wykładu oraz frekwencję uczestników.

${ }^{21}$ Por. Pismo parafialne „Dominik” wydawane przy klasztorze OO. Dominikanów w Szczecinie [Adwent 2001] s. 5.

${ }^{22}$ Dane obejmują okres 2001-2010.
} 
świecka teolożka Elżbieta Adamiak ${ }^{23}$. Jedno wydaje się pewne, że klasztor warszawski przysłużył się w zasadniczy sposób do rozwoju tego pomysłu i spowodował jego rozprzestrzenienie się na inne miasta. Dwa fakty były decydujące. Po pierwsze, założenie specjalnej strony internetowej, informującej o spotkaniach ${ }^{24}$. Stopniowo inne miasta zostały podpięte do tej sieci informacyjnej. Po drugie, zostało wypromowane logo nawiązujące do dziewięciu sposobów modlitwy św. Dominika. Znak graficzny bardzo szybko został zaadoptowany przez inne ośrodki, organizujące wykłady. Logo jest umieszczane na wszelkiego rodzaju plakatach i folderach informacyjnych, zapowiadających kolejne tematy spotkań.

We wrocławskim klasztorze dominikanów, podobnie jak w Warszawie, wykłady rozpoczęto w październiku 2002 r. Inicjatorem był ówczesny przeor klasztoru o. Przemysław Ciesielski. Po zmianie przeora klasztoru nastapiła kilkuletnia przerwa w wykładach. Wznowienie spotkań nastapiło na jesieni 2009 r. O. Przemysław Dymowski wraz z grupą kilku osób świeckich podjęli się kierowania cyklem wykładów ${ }^{25}$.

Klasztor poznańskich dominikanów zainicjował wykłady szkoły wiary w 2003 r. W organizacji cykli rocznych współpracowały trzy osoby świeckie. Spotkania były układane także w ciekawe w cykle tematyczne, z których najważniejsze dotyczyły sakramentów świętych, grzechów współczesnych oraz wiary szukającej zrozumienia. Dotychczas odbyło się 47 wykładów. Wśród prelegentów pojawiło się trzech świeckich wykładowców ${ }^{26}$.

Początek spotkań w klasztorze w Lublinie datowany jest na jesień 2007 r. Z informacji na stronie internetowej można się dowiedzieć, że wyktady te sq odpowiedziq naszego zakonu na potrzebe pogłębionej katechezy dorostych. Dotychczas odbyło się około 19 wykładów. W większości byli to dominikanie z innych klasztorów w Polsce ${ }^{27}$.

Klasztor dominikanów w Łodzi powstał stosunkowo niedawno, bo dopiero w 2004 r. Jednak od dwóch lat odbywają się także w nim wykłady szkoły wiary. Dotychczas odbyło się 11 spotkań, które są organizowane przez wspólnotę laikatu dominikańskiego ${ }^{28}$.

${ }^{23}$ Por. http://freta.szkolawiary.dominikanie.pl/.

${ }^{24}$ Por. http://www.szkolawiary.dominikanie.pl/index.html.

${ }^{25}$ Niestety archiwum spotkań DSW w Wrocławiu jest niekompletne. Trudno ustalić liczbę spotkań i dane wykładowców - por. http://www.szkolawiary.pl/.

${ }^{26}$ Por. http://www.szkolawiary.dominikanie.pl/poznan/.

${ }^{27}$ Niestety dane są bardzo niedokładne - por. http://www.szkolawiary.dominikanie.pl/lublin/.

${ }^{28}$ Por. http://www.szkolawiary.dominikanie.pl/lodz/plan.htm. 
W krakowskim klasztorze wykłady mają miejsce od 4 lub 5 lat. Nie da się tego dokładnie ustalić. Ciekawostką jest to, że istnieją one w ramach propozycji duszpasterstwa akademickiego „Beczka. Akademicka grupa inicjatywna składa się z duszpasterza i dwóch studentów. Wykłady odbywają się w środy i mają inny charakter niż w główny nurt DSW w innych polskich klasztorach ${ }^{29}$.

Po przyjeździe dominikanów do stolicy Irlandii w lutym 2006 r., od razu zainicjowano Dominikańską Szkołę Wiary. Było to przeniesienie dobrego doświadczenia z Polski. W warunkach imigracyjnych organizacja cyklu wykładów jest bardzo utrudniona. Niemniej dotychczas zorganizowano 31 spotkań $^{30}$.

Zupełną nowością i jakimś fenomenem jest zainaugurowanie na jesieni 2009 r. wykładów DSW w Piotrkowie Trybunalskim ${ }^{31}$. Nie ma tam klasztoru dominikanów, natomiast jest bardzo aktywna grupa osób świeckich, tworząca środowisko laikatu dominikańskiego. To ona właśnie podjęła się koordynowania wykładów w mieście, gdzie tradycje dominikańskie są obecne od wieków, pomimo braku wspólnoty braci dominikanów. Może to też jest bardzo dobry przykład, który udowadnia, jak wiele w tego typu działalności intelektualnej mogą znaczyć osoby świeckie.

\section{Quo vadis DSW? Wnioski i postulaty pastoralne}

\section{Sytuacja po dziesięciu latach działalności}

Jubileusze są ważne i potrzebne, jednak nie najważniejsze. Są okazją do świętowania i pozwalają na pewne podsumowania. Nie powinny prowadzić do samozadowolenia. Natomiast mogą być zaproszeniem do refleksji, co można zrobić lepiej, w oparciu o nabyte już doświadczenia. Dominikańska Szkoła Wiary ma już dziesięcioletnią historię. Stała się pewnego rodzaju propozycją dla ludzi dorosłych, ale też i wizerunkiem wykładów organizowanych przez wspólnoty dominikanów. Wielkim dobrem wspólnym są dominikańscy oraz świeccy wykładowcy, którzy uczestniczyli w tym projekcie. Poza tym cennym jest kapitał różnych przemyśleń związany z układaniem i prowadzeniem programów wykładów przez te lata. Wartością jest również bank części wykładów w wersji audio dostępnych w formie elektronicznej.

\footnotetext{
${ }^{29}$ Por. http://www.szkolawiary.dominikanie.pl/krakow/.

${ }^{30}$ Dane pochodzą z raportu sporządzonego dla diecezji dublińskiej w sierpniu 2010 r. - por. Polish Chaplaincy in Dublin: „Dominicans for Poles”. Short report: $14^{\text {th }}$ February $2006-26^{\text {th }}$ August 2010. Dublin 2010; M. G r u b k a: Dominikanie dla Polaków w Dublinie. Postuga duszpasterska w przestrzeni irlandzkiego doświadczenia wiary. „Teologia Praktyczna”. T. 8: 2007 s. 28; Por. M. L i s a k: Polscy emigranci $w$ Irlandii na przykładzie grupy osób religijnych. „Teologia Praktyczna". T. 9: 2008 s. 7-18.

${ }^{31}$ Por. http://dominikanie.pl/aktualnosci/news/archiwum/news_id,2192,y,2009.
} 
W nawiązaniu do słów generała zakonu, przywołanych u początku tekstu, znajdują się słowa o. Krzysztofa Popławskiego OP, prowincjała Polskiej Prowincji Dominikanów, pochodzące z wywiadu, udzielonego zaraz po wyborze na drugą kadencję. Stwierdził on, że Dominikańskie Szkoty Wiary, które zaczęty się dziesięć lat temu, przeżywaja już swój zmierzch, ta formuła powoli się wyczerpuje, nie jest już tak inspirujaca jak dawniej. Być może tworzenie innych zinstytucjonalizowanych formut formacji intelektualnej jest kierunkiem wartym przemyślenia $i$ zagospodarowania ${ }^{32}$. Ciekawa jest to refleksja, tym bardziej, że wypowiedziana przez jednego z pierwszych realizatorów tych wykładów i warta jest chwili zastanowienia. Pokazuje ona, że być może prowincjał widzi sens w rozwijaniu innych formuł wykładowych, natomiast nie ma już przekonania, że wykłady w ramach szkoły wiary można ukierunkować i rozwinąć, jako długoletnią propozycję formacji dla dorosłych w ramach działania całej prowincji.

$\mathrm{W}$ niedalekiej przeszłości pojawiało się w działaniach polskich dominikanów wiele różnych i może w jakimś sensie podobnych inicjatyw. Niewiele z nich przetrwało dłuższy okres czasu. Można wspomnieć o kilku z nich: „Szkoła św. Tomasza w Gdańsku” (1968-1972) ${ }^{33}$, „Studium Wiedzy Chrześcijańskiej” w Beczce (1971-1975), „Dominikańskie Studium Filozofii i Teologii” w Warszawie (2002-2006) ${ }^{34}$, czy też „Filozoficzo-Teologiczna Szkoła św. Jacka” w Rzeszowie (2009-2010) ${ }^{35}$. Była też próba otwarcia w 2005 r. w Gdańsku dominikańskiego „Kolegium Nauk Społecznych”, które docelowo nazwano „Collegium Dominicanum"36. Równocześnie warto zauważyć, że w tym roku rozpoczyna działalność Dominikańskie Studium Filozofii i Teologii w Krakowie, które stawia sobie za cel zapoznanie przyszłych słuchaczy z myślą chrześcijańską w filo-

${ }^{32} \mathrm{Na}$ księżyc, czy do Wieliczki? - z prowincjałem polskich dominikanów o. Kr z y s z to fe m Poptawskim rozmawiali Roman Bi eleckiOP iDominik JurczakOP. „W Drodze”. R. 2010 nr 3(439).

${ }^{33}$ Projekt zainicjowany przez o. L u d w i k a W i śn i e w s k i e g o, ówczesnego duszpasterza akademickiego gdańskiej „Górki”. To był bardzo śmiały pomysł formacyjny dla studentów i dorosłych.

${ }^{34}$ Projekt powstał z inicjatywy ludzi świeckich i o. T a d e u s z a B a r to s i a, wówczas dominikanina w klasztorze warszawskim. Trwał w tej formie cztery lata. Następnie został przekształcony w Warszawskie Studium Filozofii i Teologii. Prowadzony jest do dzisiaj.

${ }^{35}$ Szkoła ta nawiązuje do Studium Filozofii i Teologii istniejącego przed kilku laty w Warszawie. Warto wspomnieć, że w latach 1998-2002 istniała już próba prowadzenia Szkoły św. Jacka, którą podjął swego czasu ówczesny duszpasterz akademicki „Szopki” o. Marek Grzelczak. Szkoła zakończyła działalność wraz z jego odejściem z Rzeszowa - por. http://www.rzeszow.dominikanie.pl/szkola_sw_jacka.php.

${ }^{36}$ Szkoła została założona we współpracy z Wyższą Szkoła Administracji i Biznesu w Gdyni. W 2005 r. uzyskano pozwolenie Ministerstwa Szkolnictwa Wyższego na rozpoczęcie działalności i uruchomienie wykładów na kierunku filozofia. Jednak Kapituła Prowincjalna w 2006 r. zawiesiła ostatecznie możliwość prowadzenia tego projektu i szkoła nigdy nie przeszła etapu wstępnego por. Archiwum Klasztoru Dominikanów w Gdańsku i Fundacji Centrum św. Jacka w Gdańsku. 
zofii i teologii. Szczególny akcent ma być położony na nauczanie św. Tomasza oraz na tradycję dominikańską. Skierowana jest do absolwentów wyższych uczelni, studentów i licealistów, liderów wspólnot, animatorów i katechetów. Jednym słowem do każdego, kto chce poznać tradycję chrześcijańskiej myśli filozoficzno-teologicznej. Szkoła krakowska inicjowana jest przez wykładowców dominikańskiego Kolegium Filozofii i Teologii ${ }^{37}$. Dużo różnych inicjatyw i dobrych projektów w ostatnich kilkudziesięciu latach rozpoczynano i dość szybko i kończono ich realizację. Jest w tym jakaś słabość polskich dominikanów warta zastanowienia.

$\mathrm{Na}$ wielu stronach internetowych, ogłaszających programy szkoły wiary można znaleźć określenie „ogólnopolska sieć wykładów”. Gdyby chcieć to sprawdzić, to okazałoby się, że takie stwierdzenie odnosi się do struktury, która istnieje jedynie wirtualnie i nie pokrywa się z faktami. Raczej można zobaczyć zespół kilku monad, które nie mają do siebie żadnego odniesienia. No może jedynie stoi za tym poczucie, że tworzy się coś ważnego w oparciu o klasztory i charyzmat dominikański. Nie ma jednak żadnej struktury ogólnopolskiej. Nie ma niczego, co takim terminem dałoby się ująć. Jest jedynie wspólny szyld, jest i strona internetowa, która zresztą nie podaje wszystkich bieżących informacji. Poza tym każdy klasztor działa na własną rękę.

Poszukując informacji na głównej stronie polskich dominikanów w dziale „instytucje”, również nie znajdujemy żadnego potwierdzenia, że mamy do czynienia z siecią ogólnopolską, koordynowaną przez kogoś w imieniu prowincja$\mathrm{fa}^{38}$. Raczej można zaryzykować stwierdzenie, że tak naprawdę po upływie dziesięciu lat działalności DSW prowincja polskich dominikanów nie zajęła się w żaden sposób tą inicjatywą. Nie przeprowadzono merytorycznej refleksji i nie postawiono zadań na następne lata. Podobnie nie widnieje żaden zapis z trzech ostatnio odbytych kapituł prowincjalnych, świadczący o fakcie powołania takiej ogólnopolskiej struktury. Krótko mówiąc, również podczas ostatnich kapituł prowincjalnych nie podjęto wystarczająco głębokiej refleksji, co znalazłoby swoje odbicie w konkretnych decyzjach w aktach kapitulnych. W zapisach kapituł znajdują się raczej słowa pochwał i stwierdzenia o radości uczestników z faktu istnienia takich wykładów. Z samego faktu doceniania nie wynika jeszcze nic dla rozwoju takiej inicjatywy wykładowej ${ }^{39}$.

\footnotetext{
${ }^{37}$ Uderza zbieżność nazw z wspomnianą już szkołą założoną w warszawskim klasztorze na Służewie przez T. B a r t o s i a - por. K. W i ś n i e w s k a: Poszukiwania po czterdziestce. „Gazeta Wyborcza”, 05.07.2008 http://wyborcza.pl/1,90705,5426494,Poszukiwania_po_czterdziestce.html; zob. także - http://www.kolegium.dominikanie.pl/idea2.php.

${ }^{38}$ Por. http://dominikanie.pl/instytucje/.

${ }^{39}$ Por. Akta Zwyczajnej Kapituty Prowincjalnej Polskiej Prowincji Dominikanów. Warszawa 2002 nr 53 s. 24; tamże, nr 114 s. 35; Akta Zwyczajnej Kapituty Prowincjalnej Polskiej Prowincji
} 
Wydaje się, że przez te dziesięć lat dominikanie nie uczynili wystarczająco wiele, aby to doświadczenie i łaskę Jubileuszu Roku 2000 rozwinąc i nadać mu dojrzalszą formę. DSW może być już jakiegoś rodzaju przestrogą, aby po wyczerpaniu tematów i zmęczeniu prelegentów nie stała się kolejnym faktem historycznym, o którym można co najwyżej znaleźć informacje w dokumentach archiwum polskiej prowincji, bądź przeczytać w pracy magisterskiej.

\section{Sieć ogólnopolska, czyli kilka propozycji}

Dziesięć lat doświadczeń jest wystarczającym okresem, aby podjąć próbę sformułowania kilku wskazówek. Można się zadowolić i powiedzieć sobie, że nie ma sensu zmieniać coś, co się sprawdziło i jest dobre. Czasami takie argumenty można usłyszeć. Jednak takie myślenie niewiele wnosi. Można jednakże spróbować podjać jakieś próby, aby nadać tej formule nowe kierunki. Nie wolno stać w miejscu. W takim ujęciu pochwała generała zakonu może być czymś, co usypia i nie skłania do wysiłku.

W dominikańskiej tradycji każdy klasztor był z założenia pewnego rodzaju szkołą. Posiadał lektora konwentualnego odpowiedzialnego za kształcenie dominikanów. Może doświadczenie prowadzenia przyklasztornych szkół wiary jest ciekawym wyzwaniem dla dominikańskich wspólnot oraz dla polskiej prowincji dominikanów jako całości. Przygotowanie lektorów konwentualnych, którzy byliby zdolni do prowadzenia formacji ludzi dorosłych, a jednocześnie współtworzenia rzeczywistej sieci ogólnopolskich wykładów jest zadaniem do podjęcia.

Zagadnienie on-line learning pojawiało się w dyskusji polskich dominikanów w ostatnich latach wielokrotnie. W sposób wyraźny podczas debaty na temat życia intelektualnego polskiej prowincji w 2008 r. Czas więc już na realizację prowincjalnego projektu szkoły filozoficzno-teologicznej. Mogłaby to być szkoła stacjonarna, która miałaby prawo nadawania świadectw. A więc z możliwością distance learning. Szkoła taka mogłaby być projektem zarządzanym z centrum Polski, np. w klasztorze dominikańskim w Warszawie Służewie ${ }^{40}$. W stolicy są dwa duże klasztory o wielkim potencjale intelektualnym. To one mogłyby być miejscem, z którego rozchodzi się różnorodna propozycja nauczania przeznaczonego dla ludzi świeckich. Skoordynowany projekt pozwala na spięcie w sieć wielu innych inicjatyw, które dzieją się w dominikańskich klasztorach. W takim znaczeniu Dominikańska Szkoła Wiary mogłaby stać się projektem długofalowym, który pozwala na formułowanie możliwości dokształcenia filozoficz-

Zakonu Kaznodziejskiego. Warszawa 2006 nr 50 s. 22; Akta zwyczajnej Kapituły Prowincjalnej Polskiej Prowincji Zakonu Kaznodziejskiego. Warszawa 2010 nr 86 s. 33.

${ }^{40}$ Byłoby to nawiązanie do myśli o. prof. J a c k a W o r o n i e ck i e g o OP. 
no-teologicznego dla osób pragnących takie studium odbyć. Niezbędnym jest opracowanie programu, który byłby możliwy do realizowania w blokach tematycznych dwu, trzy i czteroletnich. Możliwa powinna być również jakaś forma podsumowania tego nauczania. Dobrze byłoby kończyć cykl nauczania wydaniem dyplomu, który umocowany byłby w systemie prawa państwowego czy kościelnego ${ }^{41}$.

Ciekawym przykładem porównawczym jest realizowany przez irlandzkich dominikanów projekt nauczania teologii pod nazwą „The Priory Institute”. Powstał on w 2000 r., czyli w tym samym czasie co projekt Dominikańska Szkoła Wiary. Dominikanie irlandzcy kierują swą propozycję do katolików świeckich, pragnących pogłębiać swoją wiarę. Klasztor w Tallaght jest miejscem skąd zarządza się tym projektem. Można studiować teologię na odległość poprzez wykorzystanie możliwości, jakie daje Internet. Studia kończą się akademickim dyplomem, który jest możliwy do uzyskania dzięki współpracy z The University of Wales w Lampeeter, w Wielkiej Brytanii ${ }^{42}$.

Ostatnim zagadnieniem jest problem zbudowania zespołów zarząadzających szkołą wiary, który składałby się z dominikanów i świeckich katolików. Jak pokazuje doświadczenie dziesięciu lat prowadzenia wykładów, nie wszędzie to było w należyty sposób zrozumiane, aby ludzi świeckich zaprosić do współtworzenia takiego przedsięwzięcia. Jeśli projekt oparty jest jedynie na przełożonych, to nie ma szans, aby stać się środowiskowym działaniem. Przełożeni są wybierani na urzędy, które są kadencyjne. Po upływie trzech lub sześciu lat odchodzą. Projekt powinien być realizowany bez względu na konieczne zmiany dokonywane w dominikańskim zakonie.

W krótkim podsumowaniu można stwierdzić, że idea powstania Dominikańskiej Szkoły Wiary oraz jej dziesięcioletnie doświadczenia niesie ciekawe przesłanie i wkład w formację ludzi dorosłych w Polsce. Jest to jedna $z$ inspirujących propozycji pastoralnych skierowanych do świeckich chrześcijan. Sama inicjatywa oraz jej modelowe przepracowanie, warta jest podjęcia dalszych wysiłków i rozwoju, tak, aby mogła stać się na coraz większą skalę dobrem pastoralnym i intelektualnym Kościoła w Polsce.

\footnotetext{
${ }^{41}$ Możliwa byłaby tutaj współpraca z którąś z istniejących w Warszawie szkół wyższych.

${ }^{42}$ Por. The Priory Institute. Theology by distance learning - http://www.prioryinstitute.com/.
} 


\section{Aneks}

\section{Wykłady Dominikańskiej Szkoły Wiary w Gdańsku (2000-2010) ${ }^{43}$}

\section{Rok akademicki 2000/2001}

21-22.10.00, o. prof. J. Salij OP (Warszawa): „Wokół dokumentu Dominus Jesus”. 17-18.11.00, o. dr J. Kupczak OP (Kraków): „Człowiek u Jana Pawła II”. 15-16.12.00, o. T. Wytrwał OP (Warszawa): „Ludzka twarz prawa” 19-20.01.01, o. dr G. Chrzanowski OP (Kraków): „Chrześcijaństwo a religie świata”. 16-17.02.01, o. K. Sonek OP (Lublin): „Którędy do Ziemi Obiecanej? Między liberalizmem a fundamentalizmem biblijnym" 16-17.03.01, o. W. Prus OP (Warszawa): „Nawrócenie św. Augustyna” 18-19.05.01, o. dr J. Puciłowski OP (Kraków): „Kościół w okresie międzywojennym” 15-16.06.01, o. prof. J. A. Kłoczowski OP (Kraków): „Czy mistyk jest osobą wierzącą?”

\section{Rok akademicki 2001/2002}

19-20.10.01, o. G. Kluz OP (Gdańsk): „Iluzja szczęścia - sekty, magia, okultyzm”

16-17.11.01, o. T. Kwiecień OP (Poznań): „Pochwała ciała, czyli liturgia i człowieczeństwo” 14-15.12.01, o. T. Trzopek OP (Lublin): Metody czytania Pisma św. i Samarytanka" 18-19.01.02, o. W. Czwichocki OP (Warszawa): „Ikona streszczeniem prawosławia” 15-16.02.02, o. prof. J. Salij OP (Warszawa): „Po co żyjemy?”

Wykład nieznany

19-20.04.02, o. dr M. Pieńkowski OP (Kraków): „Integracja europejska a tożsamość kulturowa” 13-14.06.02, o. prof. J. A. Kłoczowski OP (Kraków): „Religio postmoderna: monoteizm czy politeizm"

\section{Rok akademicki 2002/2003}

18-19.10.02, o. dr J. Puciłowski OP (Budapest): „Polak-Katolik: źródło i konsekwencje stereoty$\mathrm{pu}$ "

22-23.11.02, o. prof. J. A. Kłoczowski OP (Kraków): „, Odpowiedź na postmodernizm - filozofia dialogu"

13-14.12.02, o. dr M. Zięba OP (Warszawa): „Papieże a demokracja i kapitalizm. Od Syllabusa do Centessimus Annus"

17-18.01.03, o. Z. Krysiewicz OP (Kraków): „O spotykaniu Boga przez sztukę”

14-15.02.03, o. prof. J. Salij OP (Warszawa): „Modlitwa dominikańska: między walką a spoczynkiem"

14-15.03.03, o. M. Złonkiewicz OP (Tarnobrzeg): „Prawdziwa i fałszywa duchowość”

11-12.04.03, o. P. Kołacz OP (Warszawa): „Reguta św. Augustyna czyli korzenie duchowości dominikańskiej"

23-24.05.03, o. prof. J. A. Kłoczowski OP (Kraków): „Mistyka dominikańska: Katarzyna ze Sieny, Eckhart, Tauler ..."

13-14.06.03, o. M. Pilśniak OP (Warszawa): „Medytacja chrześcijańska”

\section{Rok akademicki 2003/2004}

10-11.10.03, o. R. Schulz OP (Wrocław): „Modlitwa dominikańska”

${ }^{43}$ Listę odtworzono z danych zawartych w archiwum Parafii i Klasztoru św. Mikołaja w Gdańsku oraz z danych uzyskanych z archiwum gdańskiej firmy reklamowej „Yellow faktory”. Podaje się kompletny plan dziesięciu lat wykładów jedynie dla ośrodka w Gdańsku. W pozostałych klasztorach wiele tych wykładów wygłoszono w innych terminach. Przyjęto jako punkt początkowy wykładów październik 2000 r., natomiast czerwiec 2010 r. przyjęto jako końcowy i dopełniający dziesięciu lat istnienia szkoły wiary. 
14-15.11.03, o. J. Głodek OP (Poznań): „Czy Polacy wierzą w Boga? - socjologia polskiego katolicyzmu"

12-13.12.03, o. W. Prus OP (Warszawa): „Św. Hieronim - przyjaźń, jako sposób czytania Pisma św."

16-17.01.04, o. prof. J. A. Kłoczowski OP (Kraków): „Mistyka i erotyka - Katarzyna ze Sieny i Henryk Suzo"

13-14.02.04, o. dr M. Zięba OP (Warszawa): „Nie obrażać się na świat”

19-20.03.04, o. dr J. Puciłowski OP (Budapest): „Dlaczego Europa odwróciła się od Kościoła?”

16-17.04.04, o. dr hab. A. Potocki OP (Warszawa): ,Jaka jest nasza wiara?”

21-22.05.04, o. T. Piłat OP (Sandomierz): „Reguła św. Benedykta. Fundament duchowości Zachodu"

\section{Rok akademicki 2004/2005}

15-16.10.04, o. M. Adamski OP (Kraków): „Żydowskie korzenie chrześcijaństwa”

12-13.11.04, o. prof. J. A. Kłoczowski OP (Kraków): „Unde malum? Skąd zło, skoro Bóg jest dobry i wszechmocny?"

17-18.12.04, o. dr M. Paluch OP (Warszawa): „Czy dogmaty są do zbawienia koniecznie potrzebne?"

21-22.01.05, o. dr M. Zięba OP (Warszawa): „Demokracja i antyewangelizacja. Religia i wolne społeczeństwo"

18-19.02.05, o. W. Jędrzejewski OP (Łódź): „Siła i kruchość czyli tajemnica chrześcijańskiej nadziei”

18-19.03.05, o. T. Kwiecień OP (Warszawa): „Geniusz liturgii”

$15-16.04 .05$, o. C. Binkiewicz OP (Warszawa): „Czy prawda istnieje naprawdę?”

20-21.05.05, o. prof. J. A. Kłoczowski OP (Kraków): „Dlaczego Bóg zgadza się na istnienie zła?”

\section{Rok akademicki 2005/2006}

14-15.10.05, o. Ł. Popko OP (Lublin): „Nie samym chlebem żyje człowiek czyli Lectio Divina”

18-19.11.05, o. dr P. Napiwodzki OP (Kraków): „Od czego wyzwala teologia wyzwolenia?”

16-17.12.05, o. B. Matusiak OP (Warszawa): „Hildegarda z Bingen. Mistyka i muzyka”

20-21.01.06, o. prof. J. A. Kłoczowski OP (Kraków): „Co wiemy o człowieku? Od homo sapiens do homo idiota"

17-18.02.06, o. J. Gonciarz OP (Korbielów): „Duchowość dominikańska”

17-18.03.06, o. M. Biskup OP (Poznań): „Eucharystia i ikona: wejście w tajemnicę”

22-23.04.06, o. M. Pilśniak OP (Warszawa): „Etyka seksualna XXI w.”

26-27.05.06, o. dr M. Przanowski OP (Kraków): „Czy Bóg ma uczucia?”

\section{Rok akademicki 2006/2007}

20-21.10.06, o. dr J. Puciłowski OP (Kraków): „PRL: działania SB przeciw Kościołowi”

24-25.11.06, o. dr T. Wytrwał OP (Warszawa): „Łaska sakramentów”

15-16.12.06, o. dr G. Chrzanowski OP (Kraków): „Dobry Bóg a zło”

19-20.01.07, o. W. Jędrzejewski OP (Łódź): „Tajemnica pojednania”

16-17.02.07, o. K. Popławski OP (Warszawa): „Kościół w Chinach. Czy ewangelizacja narodów ma sens?"

16-17.03.07, o. dr M. Paluch OP (Warszawa): „Jak Bóg jest Ojcem?”

20-21.04.07, o. dr P. Napiwodzki OP (Kraków): „Jezus Chrystus wczoraj i dziś, ten sam także na wieki"

18-19.05.07, o. dr S. Brzozecki OP (Lublin): „Rozłamy w Kościele. Arianizm. Monofizytyzm. Wielka schizma wschodnia"

Rok akademicki 2007/2008

26-27.10.07, o. W. Prus OP (Poznań): „Spowiedź - religijny rytuał, psychologiczne pocieszenie czy uzdrawiające Miłosierdzie?" 
23-24.11.07, o. dr M. Przanowski OP (Kraków): „Wiara: św. Tomasz z Akwinu i św. Jan od Krzyża"

14-15.12.07, o. W. Jędrzejewski OP (Łódź): „Tajemnica chrześcijańskiego powołania”

18-19.01.08, o. dr M. Paluch OP (Warszawa): „Czy Bogu potrzebne są ofiary?”

15-16.02.08, o. prof. J. Salij OP (Warszawa): „Cztery wykłady o Kościele”

14-15.03.08, o. W. Czwichocki OP (Wrocław): „Ojcowie pustyni czyli sens ascezy chrześcijańskiej"

18-19.04.08, o. dr T. Wytrwał OP (Warszawa): „Przestępstwa i przestępcy w Kościele”

16-17.05.08, o. W. Gołaski OP (Łódź): „Suma teologii - teologiczny testament św. Tomasza”

\section{Rok akademicki 2008/2009}

17-18.10.08, o. J. Pyda OP (Kraków): „Czy koniecznie musimy wierzyć w cuda? Chrześcijańska teologia zdarzeń niezwykłych"

21-22.11.08, o. dr P. Napiwodzki OP (Kraków): „Czy Kościół poleca wierzyć w Kościół?”

12-13.12.08, o. dr M. Zięba OP (Gdańsk): „Demokracja i wolny rynek w Ewnagelii czyli chrześcijanin w polityce i gospodarce"

16-17.01.09, o. K. Karbownik OP (Kraków): ,Jak się spowiadać by się dobrze spowiadać?”

13-14.02.09, o. dr J. Puciłowski OP (Kraków): „Czy jest możliwa wiara bez kryzysu? O czym świadczą trudności w wierze?"

27-28.03.09, o. dr R. Plich OP (Kraków): „Czy żyjemy dla zakazów, czy zakazujemy, aby żyć? Uzasadnienie katoliciej etyki seksualnej”

24-25.04.09, o. W. Jędrzejwski OP (Łódź): „Sztuka sprzeciwu czyli jak reagować na zło”

22-23.05.09, o. T. Zamorski OP (Łódź): „Dojrzałość wiary - dojrzałość życia. Miłosny uścisk między psychoterapią a wiarą"

Rok akademicki 2009/2010

23-24.10.09, o. T. Kwiecień OP (Łódź): „Powszechne kapłaństwo wszystkich chrześcijan”

20-21.11.09, o. dr M. Zięba OP (Gdańsk): „Czego uczy nas dzisiejszy kryzys?”

11-12.12.09, o. dr M. Paluch OP (Warszawa): „O czym nie można nie (po)wiedzieć. Jak się myśli dziś o Chrystusie w Kościele?"

22-23.01.10, o. T. Gaj OP (Warszawa): „Czy psychologia zagraża wierze?”

19-20.02.10, o. C. Klahs OP (Poznań): „O nadziei i zniechęceniu”

12-13.03.10, o. dr P. Napiwodzki OP (Kraków): „Czy Kościół głosi jeszcze koniec świata?”

23-24.04.10, o. M. Paluch OP (Warszawa): „Jak myśli się dziś o Chrystusie w Kościele?”

21-22.05.10, o. dr G. Chrzanowski OP (Kraków): „Czy istnienie Boga można udowodnić?” 